\title{
Myeloid-derived suppressor cells therapy enhance immunoregulatory properties in acute graft versus host disease with combination of regulatory T cells
}

Min-Jung Park', Jin-Ah Baek', Se-Young Kim', Kyung-Ah Jung ${ }^{1}$, Jeong Won Choi', Sung-Hwan Park ${ }^{1,2}$, SeungKi Kwok ${ }^{1,2}$ and Mi-La Cho ${ }^{1 *}$ (1)

\begin{abstract}
Background: Myeloid-derived suppressor cells (MDSCs) play a critical role in modulating the immune response and promoting immune tolerance in models of autoimmunity and transplantation. Regulatory $T$ cells (Tregs) exert therapeutic potential due to their immunomodulatory properties, which have been demonstrated both in vitro and in clinical trials. Cell-based therapy for acute graft-versus-host disease (aGVHD) may enable induction of donor-specific tolerance in the preclinical setting.

Methods: We investigated whether the immunoregulatory activity of the combination of MDSCs and Tregs on T cell and $B$ cell subset and alloreactive T cell response. We evaluated the therapeutic effects of combined cell therapy for a murine aGVHD model following MHC-mismatched bone marrow transplantation. We compared histologic analysis from the target tissues of each groups were and immune cell population by flow cytometric analysis.

Results: We report a novel approach to inducing immune tolerance using a combination of donor-derived MDSCs and Tregs. The combined cell-therapy modulated in vitro the proliferation of alloreactive T cells and the Treg/Th17 balance in mice and human system. Systemic infusion of MDSCs and Tregs ameliorated serverity and inflammation of aGVHD mouse model by reducing the populations of proinflammatory Th1/Th17 cells and the expression of proinflammatory cytokines in target tissue. The combined therapy promoted the differentiation of allogeneic $T$ cells toward Foxp3 + Tregs and IL-10-producing regulatory B cells. The combination treatment control also activated human T and B cell subset.

Conclusions: Therefore, the combination of MDSCs and Tregs has immunomodulatory activity and induces immune tolerance to prevent of aGVHD severity. This could lead to the development of new clinical approaches to the prevent aGVHD.
\end{abstract}

Keywords: Myeloid-derived suppressor cells, Regulatory T cells, Graft-versus-host disease, Immune tolerance, Cell therapy

\footnotetext{
*Correspondence: iammila@catholic.ac.kr

${ }^{1}$ The Rheumatism Research Center, Catholic Research Institute of Medical Science, The Catholic University of Korea, 505 Banpo-dong, Seocho-gu, Seoul 137-040, South Korea

Full list of author information is available at the end of the article
}

\section{Background}

Graft-versus-host disease (GVHD) is the major complications after allogeneic hematopoietic stem cell transplantation (Allo-HSCT) [1, 2]. During GVHD, allogenic $\mathrm{T}$ cells are differentiated into effector lineages and

(c) The Author(s) 2020. This article is licensed under a Creative Commons Attribution 4.0 International License, which permits use, sharing, adaptation, distribution and reproduction in any medium or format, as long as you give appropriate credit to the original author(s) and the source, provide a link to the Creative Commons licence, and indicate if changes were made. The images or other third party material in this article are included in the article's Creative Commons licence, unless indicated otherwise in a credit line to the material. If material is not included in the article's Creative Commons licence and your intended use is not permitted by statutory regulation or exceeds the permitted use, you will need to obtain permission directly from the copyright holder. To view a copy of this licence, visit http://creativeco mmons.org/licenses/by/4.0/. The Creative Commons Public Domain Dedication waiver (http://creativecommons.org/publicdomain/ zero/1.0/) applies to the data made available in this article, unless otherwise stated in a credit line to the data. 
secrete proinflammatory cytokines [3]. Allogeneic T-cell response are suppressed by immunosuppressive drugs, reducing the risk for acute GVHD $[4,5]$. However, immunosuppressive drug for GVHD result in toxic side-effects. Thus, there is an unmet need for novel treatment strategies for GVHD with less toxicity and fewer side effects.

Myeloid-derived suppressor cells (MDSCs) are a heterogeneous population of immature myeloid cells that negatively regulate the immune response $[6,7]$. MDSCmediated immunosuppression involves increased arginase- 1 and inducible nitric oxide synthetase (iNOS) activity and induction of T-cell apoptosis. MDSCs are effective against experimental autoimmune rheumatoid arthritis, systemic lupus erythematosus (SLE), and inflammatory bowel disease (IBD) [8-10]. Recently, MDSCs also promote immune tolerance in the context of organ transplantation [11, 12], and have therapeutic potential in T-cell-mediated diseases, but their efficacy is controversial.

MDSCs can be differentiated and expanded in vitro by various methods using a variety of combinations of progenitor cells and cytokines [13]. MDSCs generated in vitro suppress autoimmune lupus [14] and prevent in a pre-clinical GVHD model [15-17], indicating therapeutic potential for T-cell-mediated diseases.

Regulatory $\mathrm{T}$ (Tregs) cells exert an immunoregulatory role and induce Immunological tolerance $[18,19]$. CD4 + CD25 + Foxp3 + Treg-based cellular therapy is effective for recipients of bone marrow and solid organ transplantation [20-22] and in patients with autoimmune diseases [23]. Donor-derived Tregs are typically used, as they share an MHC type with CD4+ and CD8 + T cells, which are primarily responsible for GVHD [24]. However, the therapeutic potential of Tregs is limited by their short lifespan and their plasticity under pathological conditions [25-27].

MDSC and Treg cell interactions involve a positive feedback signals in which MDSCs expand Treg cells while Treg cells control MDSC function [28]. MDSC support the induction of regulatory B (Breg) cells [14], type of B cell that releases IL-10 and and has immunosuppressive effects $[29,30]$. Given this background, combined cell therapy using MDSCs and Treg cells may be beneficial for the treatment of aGVHD. We investigated the effects of the combination of MDSCs and Tregs on the induction of tolerance to MHC-mismatched transplants. The combination of MDSCs and Tregs reciprocally modulated the populations of alloreactive Th1/Th17 cells and Foxp3 + Treg cells. Furthermore, the combination therapy alleviated aGVHD clinically and histopathologically by regulating the effector $\mathrm{T} / \mathrm{B}$ cell and Treg/Breg balance. These findings indicate that the combination of MDSCs and Tregs shows promise for alleviating aGVHD.

\section{Methods}

Mice

8-weeks-old C57BL/6 (B6, H-2b) and BALB/c (H-2d) female mice were purchased from Orient Bio (Sungnam, South Korea). The mice were maintained under specific-pathogen-free conditions in an animal facility with controlled humidity $(55 \pm 5 \%), 12 / 12 \mathrm{~h}$ light/ dark cycle, and temperature $\left(22 \pm 1{ }^{\circ} \mathrm{C}\right)$. Mice were fed mouse chow and tap water ad libitum. All animal experiments were performed in accordance with the animal care and use committee of The Catholic University of Korea approved the protocols.

\section{Generation of MDSCs}

Bone marrow mononuclear cells cells (BMMCs) were flushed out the bone marrow cavity of tibias and femurs with $\alpha$-minimum essential medium (Invitrogen). BMMCs were cultured in 6 well plate at $1 \times 10^{6}$ cells $/ \mathrm{mL}$ in complete medium supplemented with GMCSF $(20 \mathrm{ng} / \mathrm{mL}$ ) and M-CSF $(20 \mathrm{ng} / \mathrm{mL}$ ) (both from $R \& D$ Systems). After three days, they were harvested and stained with CD11c, CD11b, and Gr-1 antibodies after blocking Fc receptors (all from BD Biosciences). CD11c-, CD11b+, and Gr-1+MDSC populations were sorted using a MoFlo cell sorter (Beckman Coulter). Human PBMC were cultured in 6 well plate at $1 \times 10^{6} \mathrm{cells} / \mathrm{ml}$ in complete medium supplemented with GM-CSF $(20 \mathrm{ng} / \mathrm{ml})$ and IL-6 $(20 \mathrm{ng} / \mathrm{ml}$ ) (both from R\&D Systems). After three days, Lineage - /HLA$\mathrm{DR}-/ \mathrm{CD} 33+/ \mathrm{CD} 11 \mathrm{~b}+$ human MDSC subsets were sorted using a MoFlo cell sorter (Beckman Coulter). The purity of the sorted MDSCs was $>95 \%$.

\section{Generation of Tregs}

Mouse splenic CD4+ T cell were isolated from spleen by using mouse anti-CD4 microbeads (Miltenyi Biotec, Germany). To isolate Treg cells, CD4+ T-cells were cultured with plate-bound anti-mouse CD3 $(1 \mu \mathrm{g} / \mathrm{mL}$; BD Biosciences), soluble anti-mous CD28 $(1 \mu \mathrm{g} / \mathrm{mL}$; BD Biosciences $)$, anti-IFN- $\gamma(2 \mu \mathrm{g} / \mathrm{ml})$, anti-IL-4 $(2 \mu \mathrm{g} /$ $\mathrm{ml})$, human recombinant transforming growth factor $-\beta$ (TGF- $\beta ; 5$ ng/mL; PeproTech, London, UK), and Retinal $(0.1 \mu \mathrm{M}$; Sigma-Aldrich, St. Louis, MO)(16).

Human $\mathrm{CD} 4+\mathrm{T}$ cells were isolated from PBMC by using human anti-CD4 microbeads (Miltenyi Biotec, Germany). To isolate human Treg cells, human CD4+T-cells were cultured with plate-bound antihuman CD3 $(1 \mu \mathrm{g} / \mathrm{mL})$, soluble anti-human CD28 $(1 \mu \mathrm{g} / \mathrm{mL})$, anti-IFN- $\gamma(2 \mu \mathrm{g} / \mathrm{ml})$, anti-IL-4 $(2 \mu \mathrm{g} / \mathrm{ml})$, human recombinant TGF- $\beta(5 \mathrm{ng} / \mathrm{mL})$ and Retinal $(0.1 \mu \mathrm{M})$. 
After three days, the induced Treg cells were stained with CD4, CD25 and then sorted using a MoFlo cell sorter to obtain a $\sim 95 \%$ pure CD $4+$ CD25 + population.

\section{Alloreactive T-cell responses in vitro}

Responder CD4 $+\mathrm{T}$ cells (responder cells) were derived from Balb/c mice. Antigen-presenting cells (APCs: T-cell-depleted splenocytes) were isolated from Balb/c (syngenic) or B6 (allogenic) mice and irradiated with 3,000 cGy. Responder cells $\left(1 \times 10^{5}\right)$ and irradiated $\operatorname{APCs}\left(1 \times 10^{5}\right)$ were cocultured in 96-well plates for 4 days, pulsed with $1 \mu \mathrm{Ci}$ tritiated thymidine $(3[\mathrm{H}]-\mathrm{TdR}$; NEN Life Science Products Inc., Boston, MA) at $18 \mathrm{~h}$ before the end of the experiment, and counted using an automated harvester (PHD Cell Harvester; Cambridge Technology, Inc., Cambridge, MA).

\section{In vitro co-culture systems}

In FACS analysis, mouse or human $\mathrm{CD} 4+\mathrm{T}$ cells $\left(1 \times 10^{6}\right)$ were cocultured with MDSC or Treg alone or combined MDSC $\left(2 \times 10^{5}\right)$ and Treg $\left(2 \times 10^{5}\right)$ cells for 3 days in the presence of anti-mouse CD3 antibody $(0.5 \mathrm{ug} / \mathrm{ml})$. In the mixed lymphocyte reaction assay, responder $\mathrm{CD} 4+\mathrm{T}$ cells $\left(1 \times 10^{5}\right)$ were cocultured with MDSC or Treg alone or combined MDSC $\left(2 \times 10^{4}\right)$ and Treg $\left(2 \times 10^{4}\right)$ cells for 4 days in the presence of antimouse CD3 antibody $(0.5 \mathrm{ug} / \mathrm{ml})$. For all experimental conditions, MDSCs or Treg to T cells ratio is 1:5.

\section{Bone marrow transplantation}

To develop the aGVHD model, Balb/c were lethally irradiated with 700 cGy and infused with $5 \times 10^{6}$ donor BM cells plus $5 \times 10^{6}$ splenocytes from Balb/c(syngenic) or C57BL/6(donor, allogenic) on day 0. On day1 and day7 after bone marrow transplantation (BMT), recipient mice received MDSCs $\left(1 \times 10^{6}\right)$ and Tregs $\left(1 \times 10^{6}\right)$ individually or in combination. The mice were monitored for clinical signs and body weight. The clinical GVHD was scored twice weekly using the clinical GVHD scoring system (Additional file 1: Table S1) [31]. Each of the five clinical parameters summed up to get the final score at indicated time points.

\section{Histological and immunohistochemical analyses}

Mice were sacrificed on day 28 after BMT and organs captured, cryoembedded, and sectioned. Tissue specimens were fixed in $10 \%$ formalin buffer and embedded in paraffin. Sections $(6 \mu \mathrm{m}$ thick) were stained with H\&E and the histologic score was determined using established scoring systems [31, 32]. For immunohistochemistry staining, sections were stained with primary antibodies against IL-6 [Abcam, Cambridge, England (ab7737)], IL-17 [Abcam (ab79056)], TNF- $\alpha$ [Abcam (ab6671)] and Foxp3 [H-190, Santa Cruz Biotechnology (sc-28705)] overnight at $4{ }^{\circ} \mathrm{C}$, followed by addition of a biotinylated secondary antibody and a streptavidin-peroxidase mixture for $1 \mathrm{~h}$. Color was developed by addition of 3,3-diaminobenzidine (Dako, Carpinteria, CA).

\section{Flow cytometry analysis}

Mouse lymphocytes were stained with following fluorochrome conjugated antibodies: CD4(L3T4)-PerCP Cy5.5, CD25(PC61)-APC, Foxp3(FJK-16 s)-PE, IFN$\gamma$ (XMG1.2)-APC, IL-17(eBio17B7)-FITC, B220(RA36B2)-APC, CD19(eBio1D3(1D3))-PerCP, CD1d(1B1)- PE, CD5(53-7.3)-FITC, IL-10(JES5-16E3)-APC, CD138(2812)-PE, and T- and B-Cell Activation Antigen (GL7)-FITC. Human lymphocytes were stained with following fluorochrome conjugated antibodies: CD4(RPA-T4)-PECy7, CD25(BC96)-APC, Foxp3(259D/C7)-PE, IFN- $\gamma(4 S . B 3)-$ APC, IL-17(eBio64DEC1-FITC, CD19(HIB19)-FITC, IL-10(JES3-19F1)-APC， CD138(MI15)-PB450. Before intracellular staining, cells were stimulated for $4 \mathrm{~h}$ with phorbol myristate acetate $(25 \mathrm{ng} / \mathrm{mL})$ and ionomycin $(250 \mathrm{ng} / \mathrm{mL}$ ) in the presence of Golgistop (BD Biosciences, San Jose, CA, USA). Intracellular staining was fixed using a BD Cytofix/ Cytoperm Plus Fixation/Permeabilization Kit and BD Golgistop Kit (BD Biosciences, San Jose, CA). Foxp3, transcription factor was fixed using a Foxp3/ Transcription Factor Staining buffer set (eBioscience, San Diego, CA) following the manufacturer's instructions. Flow cytometric analysis was performed using a cytoFLEX Flow Cytometer (Beckman Coulter, Brea, CA, USA) and collected data were analyzed using the FlowJo software (Tree Star, Ashland, OR).

\section{Enzyme-linked immunosorbent assay}

The concentrations of IL-17 and IFN- $\gamma$ in culture supernatants were measured in duplicate using a sandwich enzyme-linked immunosorbent assay (ELISA) according to the manufacturer's protocol (DuoSet; R\&D Systems, Lille, France).

\section{Statistical analyses}

Data are expressed as the means \pm standard error of the mean (SEM). One-way analysis of variance followed by Bonferroni's post hoc test was used to compare the differences between three or more groups. Statistical significance was considered as $P$ value $<0.05$. All statistical analysis was performed with Prism (standard version 5.01; GraphPad Software, San Diego, CA). 


\section{Results}

The combination of MDSCs and Tregs controls the T cell and $B$ cell response

To titrate of MDSC or Treg: T cells ratio in vitro coculture experiments, we performed using 3 dose (1/20:1,1/5:1,1:1 ratio, E:T ratio) evaluating Treg and Th17 cell regulation. However, MDSC or Treg: T cells (1:1) ratio is excluded in combined treatment. We chosen highly efficient ratio of 1:5 ratio in regulation of Treg/Th17 by Tregs and MDSCs combined therapy (Additional file 2: Figure S1). To evaluate the effects of the combination of MDSCs and Tregs on T- and B-cell subsets, we cultured CD4+ T cells from C57BL/6 spleen with MDSCs and Tregs individually or in combination for 3 days in vitro. The Th1 and Th17 cell populations were significantly reduced, and the Foxp3 + Treg population was significantly increased, by the combination treatment compared to either cell type alone (Fig. 1a). C57BL/6 splenocytes were incubated with LPS for 3 days in the presence of MDSCs and Tregs individually or in combination. The combination treatment markedly increased the population of IL-10-producing Bregs (Fig. 1b) and significantly reduced the plasma cell population compared to the control and MDSCS or Tregs alone (Fig. 1b).

To determine whether combination treatement of MDSC and Treg has a inhibitory effect on proliferation of alloreactive $\mathrm{T}$ cells, we performed in vitro alloreactive proliferation assay. Alloreactive $\mathrm{CD}^{+} \mathrm{T}$ cells had proliferated vigorously to allogenic stimulation. MDSCs or Tregs alone suppressed the proliferation of alloreactive $\mathrm{T}$ cells. The combination more potently diminished the proliferation of alloreactive $\mathrm{T}$ cells (Fig. 2a). Under alloreactive $\mathrm{T}$ cell-activation conditions, elevated interferon (IFN) $-\gamma$ and IL-17 levels were markedly reduced by the combination treatment, compared to treatment with either cell type alone (Fig. 2b).

Next, we assessed the effects of combined therapy with MDSCs and Tregs on alloreactive $\mathrm{T}$ cell subsets. Combined therapy increased the population of $\mathrm{CD}^{+}{ }^{+} \mathrm{Foxp}^{+}$ Treg cells approximately threefold (Fig. 2c) but reduced the population of effector Th1 and Th17 cells (Fig. 2c).

\section{The combination of MDSCs and Tregs ameliorates acute GVHD severity and inflammation}

To evaluate whether combined cell-therapy with MDSCs and Treg could therapeutic potential for aGVHD model. We used a fully MHC-mismatched $\left(\mathrm{BALB} / \mathrm{c}\left(\mathrm{H}-2 \mathrm{k}^{\mathrm{d}}\right) \rightarrow \mathrm{C} 57 \mathrm{BL} / 6(\mathrm{H}-2 \mathrm{~kb})\right.$ murine models (Fig. 3a). There were no differences in weight loss among the groups, while the animals treated with the combination had lower clinical scores than the control and MSC- or Treg-alone treated animals (Fig. 3b).
The skin, liver, lung, and intestine are the primary targets of aGVHD. According to histopathologic analyses of the intestine, skin, liver and lung, the extent of tissue damage, inflammation, and lymphocyte infiltration was significantly reduced by the combined cell therapy compared to those of control mice and MDSCs or Tregs alone treated mice (Fig. 3c-e).

Proinflammatory cytokines, including IL-6, IL-17 and TNF- $\alpha$, are key mediators of injury to target organs. To determine whether combined therapy with MDSCs and Tregs modulate the production of proinflammatory cytokines in target tissues, we performed immunohistological staining of IL-17, IL-6, TNF- $\alpha$, and Foxp3 in the skin, liver, lung, and small intestine. As shown in Fig. 4 and Additional file 3: Figure S2, the expression level of IL-17, IL-6, and TNF- $\alpha$ was lower in sections of skin, liver, lung, and intestine tissue by the combined cell therapy compared to the control and to each cell type individually. Foxp3+cells were also observed in the stroma region of target tissue, but majority of Foxp $3+$ cells was observed in lymphocyte infiltration region. Combined treatment significantly increased Foxp $3+$ cells compared with single treatment (Additional file 3: Figure S2).

\section{The combination of MDSCs and Tregs modulates T- and B-cell populations in vivo}

To determine the in vivo mechanism of action of the combination cell therapy during the development of aGVHD, we analyzed the T helper subsets by flow cytometry. In peripheral blood, the Th1 and Th17 cells were significantily reduced by the combination of MDSCs and Tregs (Additional file 4: Figure S3). The population of Th2 cells slightly expanded and did not differ among the groups. Interestingly, the Foxp3 + Treg population was increased by the combined cell therapy compared to the control and to treatment with MDSCs or Tregs alone (Additional file 1: Figure S1). Furthermore, the frequency of Th1 and Th17 cell in the spleen were significantly decreased by the combination therapy with MDSCs and the populations of Tregs. In contrast, the proportion of Foxp3 + Tregs (Fig. 5a) and IL-10 + Bregs were markedly increased (Fig. 5b).

To explore the regulatory effects of the combined cell treatment on B-cell subsets in vivo, we analyzed the populations of germinal-center B cells, plasma cells, and IL-10 producing Bregs by flow cytometry. The combination significantly decreased the populations of germinal-center B cells and plasma cells. Interestingly, the population of IL-10+Bregs was increased by the combined cell therapy compared to the control and treatment with MDSCs or Tregs alone (Fig. 5b). 

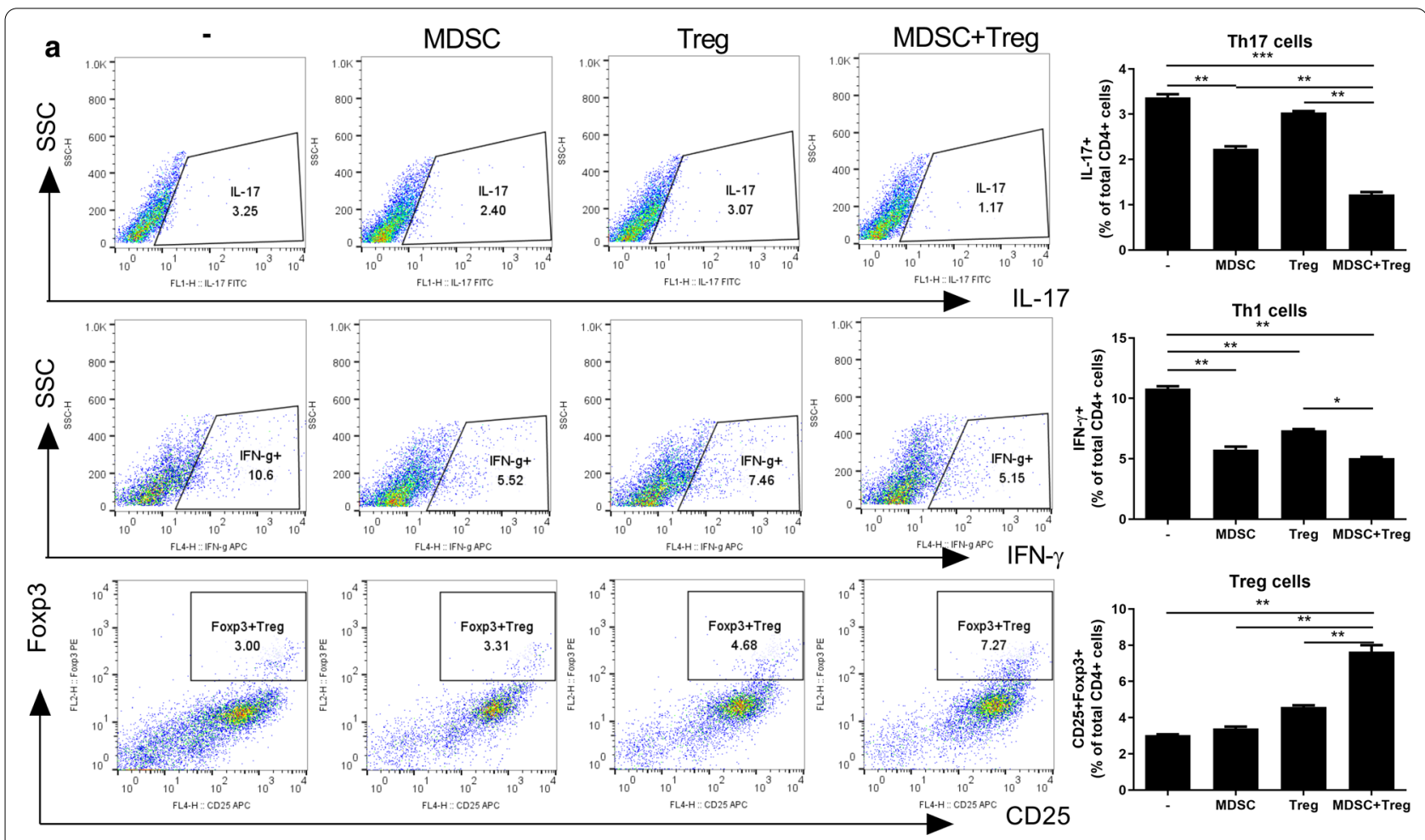

b

MDSC

Treg
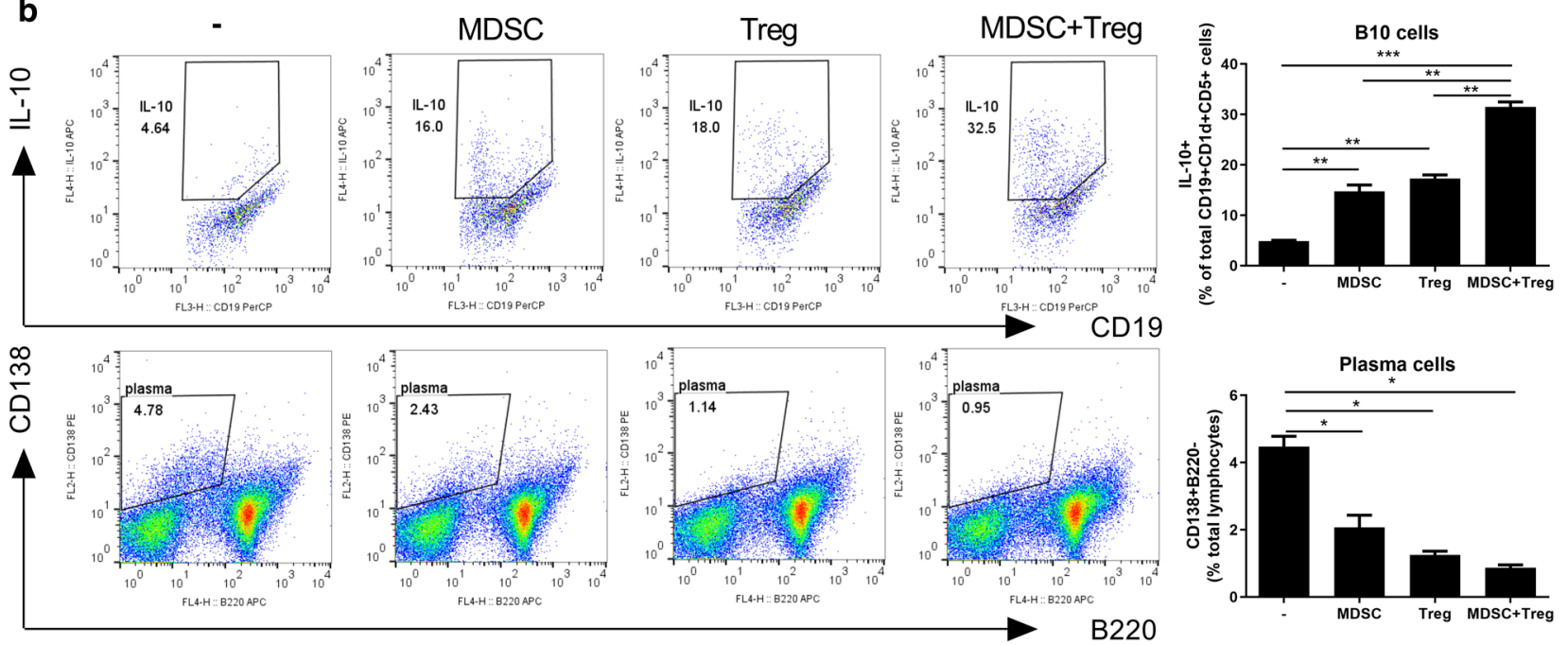

Fig. 1 Combined treatment with MDSCs and Treg regulates T cell and B cell response. a CD4 + T cell $\left(1 \times 10^{6}\right)$ isolated from normal C57BL/6 mice were cocultured with MDSC or Treg alone or combined $\operatorname{MDSC}\left(2 \times 10^{5}\right)$ and Treg $\left(2 \times 10^{5}\right)$ cells for 3 days in the presence of anti-mouse CD3 antibody and analyzed by flow cytometry. A plot from one representative experiment displays the proportions of IL-17+, IFN- $\gamma+$, CD25 + Foxp3 + cells among CD4 + T cells. Numbers in the plots indicate percentages of gated cells. $\mathbf{b}$ Total splenocytes $\left(1 \times 10^{6}\right)$ of normal C57BL/6 mice coculture with MDSC or Treg alone or combined MDSC and Treg cells for 3 days in the presence of LPS (100 ng/ml) and analyzed by flow cytometry. A plot from one representative experiment displays the proportions of IL-10+CD19+ cells, CD138+ B220- cells. Numbers in the plots indicate percentages of gated cells. Data are means \pm SEMs. Data are representative of three independent experiments $\left({ }^{*} p<0.05,{ }^{* *} p<0.01\right.$, $\left.{ }^{* * *} p<0.001\right)$

\section{Effects of combined therapy with MDSCs and Tregs} on human $\mathrm{T}$ - and B-cell subsets

To determine the effects of combined therapy on human $\mathrm{T}$-cell subsets, we analyzed the populations of effector
$\mathrm{T}$ cell subsets by flow cytometry. As shown in Fig. 6a, in vitro coculture with MDSCs and Tregs reduced the populations of Th1 and Th17 cells compared to coculture with either of those cell types individually. By contrast, 


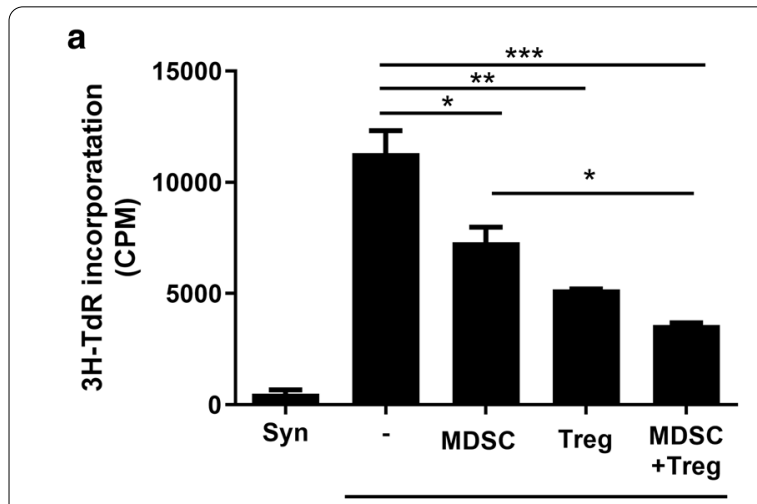

Alloresponse
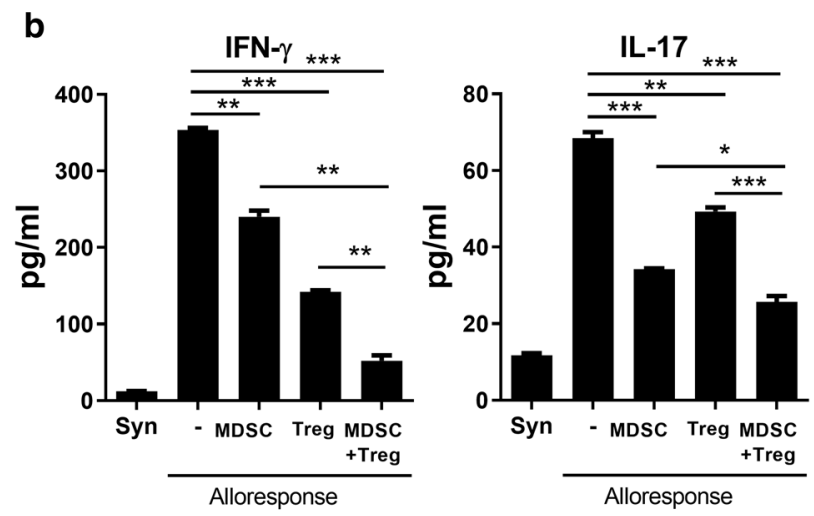

C
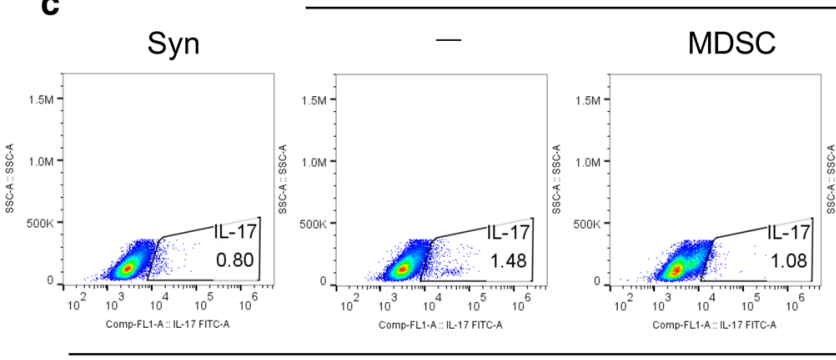

Alloresponse
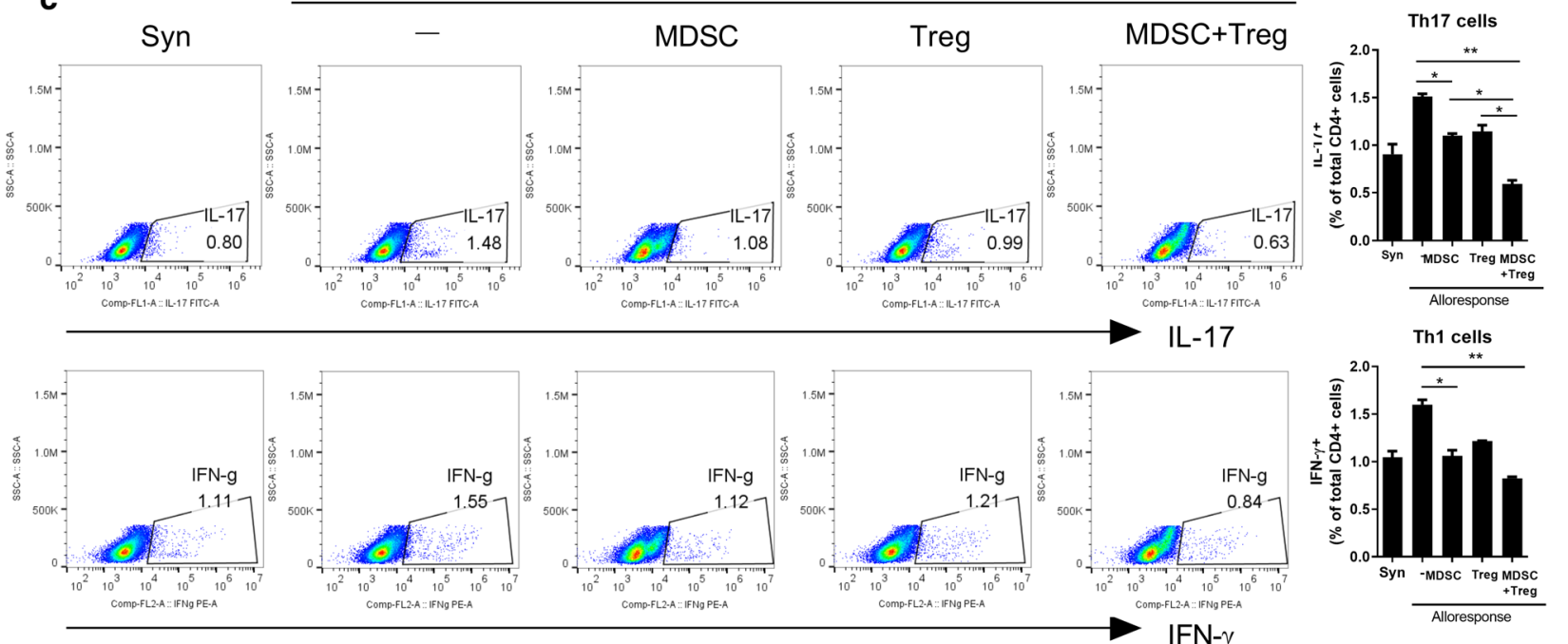

IFN- $\gamma$
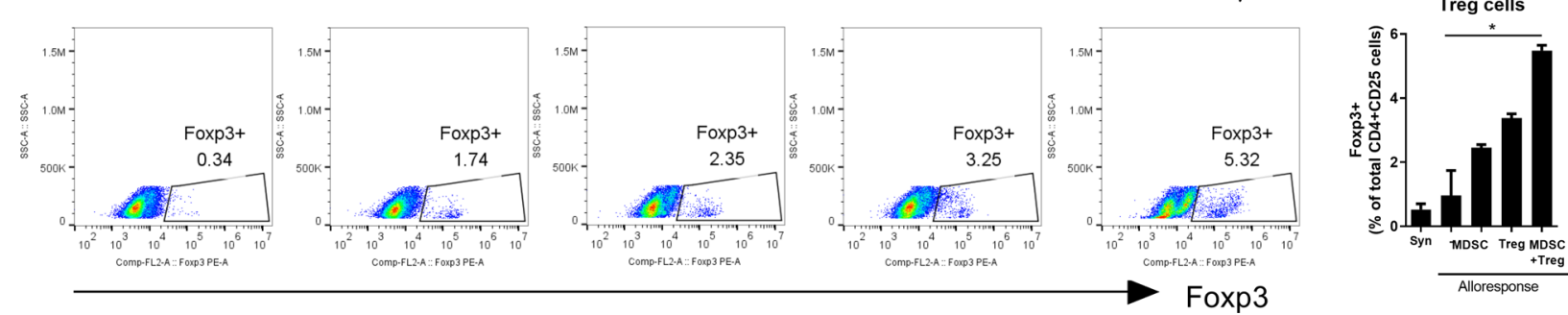

Fig. 2 Combined treatment with MDSCs and Treg control alloreactive T cell response. a In the mixed lymphocyte reaction assay, a total of $1 \times 10^{5}$ B/C splenic T cells (responders) were incubated with $1 \times 10^{5}$ irradiated B/C (syngeneic stimulators, Syn) or B6 (allogeneic stimulators, Allo]) splenic APCs for 4 days. Responder cells were cultured in the presence or absence of MDSC $\left(2 \times 10^{4}\right)$ or/and Treg $\left(2 \times 10^{4}\right)$. b IFN- $\gamma$ and IL-17 levels in the supernatants were measured by ELISA. c Intracellular immunostaining of IL-17+CD4+, IFN- $\gamma+C D 4+$, Foxp3 + Treg cells was performed were determined by flow cytometry. Data are means \pm SEMs. Data are representative of three independent experiments $\left({ }^{*} p<0.05,{ }^{* *} p<0.01,{ }^{* * *} p<0.001\right.$ versus alloresponse)

the population of Foxp3 + Tregs was increased by the combined cell therapy compared to the control and treatment with MDSCs or Tregs alone.

Furthermore, the proportion of IL-10-producing B cells was increased by the combination cell therapy compared to the control and treatment with MDSCs or Tregs alone (Fig. 6b). However, the population of CD138+ plasma cells did not differ among the groups. 


\section{Discussion}

GVHD may develop after allogeneic HSCT is used to treat hematologic malignancies. The standard therapy for aGVHD is steroids and calcineurin inhibitors, but the long-term use of such nonspecific immunosuppressive drugs causes severe side effects [5]. Thus, more effective treatment strategies for acute GVHD urgently needed.

MDSCs are potent immunosuppressive cells in various pathologic settings. They can inhibit T-cell responses both in vitro and in vivo by producing factors such as arginase 1 , iNOS, reactive oxygen species, and TGF- $\beta$, which inactivate a variety of immune cell types, particularly $\mathrm{T}$ cells [6]. MDSC induce expansion of Tregs $[28,33]$. In addition, MDSCs promote the expansion of Breg cells (IL-10-producing B cells) via an iNOS-dependent pathway and ameliorate autoimmune disorders [14].

In recent studies, MDSCs have potential for the treatment of GVHD [16, 17, 34]. However, our data show that MDSCs alone had low clinical efficacy. Highfill et al. showed that an IL-13-producing subset of MDSCs had a greater suppressive effect than MDSCs [15]. MDSC show promise as potential cell therapy for the treatment GVHD, however the regulatory role of myeloid cells is poorly understood and still lack of a clinical research for the application.

Tregs can control GVHD in mice $[35,36]$ and humans $[37,38]$ by inhibiting the alloreactive $\mathrm{T}$-cell response. They have shown positive results in preclinical trials and their ability to ameliorate GVHD is under investigation. However, this approach requires standardization of Treg expansion methods and doses [39, 40]. Inducible Tregs can readily be generated, but controversial preclinical findings and phenotype instability have hampered their translation to the clinic [18].

In previous study, for the first time that murine MDSCs induced expansion Breg cells (IL-10-producing $B$ cells) have therapeutic effect in an animal model of SLE [14]. Bregs have significant immunosuppressive abilities both in vitro and in vivo. Bregs prevent the onset of GVHD by inhibiting the differentiation of Th1 and Th17 cells and promoting the expansion of
Tregs $[29,41,42]$. Therefore, MDSC-mediated expansion of Bregs is important for the treatment of aGVHD. Our data confirm that our combination therapy with MDSCs Tregs has potential for ameliorating GVHD.

We first analyzed the regulatory effect of $\mathrm{T}$ and $\mathrm{B}$ cell subset by combination therapy of MDSC and Treg. As reported in previous studies, our results confirmed an increase in Treg and a decrease in Th1 and Th17 cells by MDSC or Treg cells alone, but the combination treatment confirmed a more synergistic immunomodulatory effect. The combination of MDSCs and Tregs simultaneously induced Treg skewing and Th1/Th17 suppression, increased the frequency of IL-10-producing Bregs, and decreased the frequency of plasma cells. It also controlled the proliferation of alloreactive T cells and the Treg/Th17 balance in vitro. These data suggest that the combination of MDSCs and Tregs has potent immunoregulatory effects in mice and humans.

Systemic combined treatment of MDSCs and Treg cells improved clinical GVHD severity, effectively modulating the $\mathrm{T}$ helper cell response, reduced the percentage of alloreactive of Th1, and Th17 cells, and increased the frequencies of Th2 and Foxp3 + Treg cells. In vivo, the combination decreased the population of germinal center B cells and plasma cells and increased that of IL-10-producing Bregs. Thus, the combination cell therapy directly modulated the reciprocal regulation of CD4 $+\mathrm{T}$-cell and B-cell subsets. Moreover, the expression of proinflammatory cytokine (IL-6, IL-17 and TNF- $\alpha$ ) decreased, and that of Foxp3 increased, in the GVHD target tissues (skin, liver, lung, and intestine) from mice treated with MDSC and Treg, suggesting that the in vivo suppressive activity of the combination therapy is attributable in part to soluble mediators. Future studies should investigate the immunoregulatory mechanisms and the interactions of the combination of MDSCs and Tregs for their therapeutic application.

Previous reports suggest that the combination of MSCs and Treg cell therapy have enhanced therapeutic efficacy in transplantation model [43-45]. However, the mechanism underlying cross talk between MSC and Treg remains unclear [46]. MSC therapy have also been proposed as a treatment for steroid-refractory GVHD but

\footnotetext{
(See figure on next page.)

Fig. 3 Combined cell-therapy with MDSCs and Treg attenuate the severity of aGVHD. a Schematic representation of the development of acute GVHD after allogeneic BMT. Splenocytes $\left(5 \times 10^{6}\right)$ plus bone marrow cells $\left(5 \times 10^{6}\right)$ from Balb/c (syngeneic, $\left.n=3\right)$ or B6 mice (allogeneic, $\left.n=15\right)$ were transplanted into irradiated B/c mice (recipient, $n=25)$ via intra-vein injection. After BMT, recipients were divided into 5 groups $(n=10$ per group) followed by IV injection with MDSCs $\left(1 \times 10^{6}\right)$ and Tregs $\left(1 \times 10^{6}\right)$ individually or in combination (MDSC + Treg, MT) on days 1, 7. b Weight, weight change, clinical score were monitored in mice with aGVHD. Combined data from 2 independent experiments are displayed. $\mathbf{c}$ Histopathological analysis of the small intestine, skin, liver and lung at 28 days after BMT. The sections were stained with hematoxylin and eosin (Intestine, liver:original magnification, $\times 40$, skin, lung:original magnification, $\times 100$ ). $\mathbf{d}$ The lower panel (original magnification, $\times 200$ ) is the zoom-in image in the arrow region of the left panel. e Bar represent the average the histological scores of the small intestine, skin, liver and lung. Data are representative of 2 independent experiments $\left({ }^{*} p<0.05,{ }^{* *} p<0.01,{ }^{* * *} p<0.001\right.$ versus control (vehicle) GVHD)
} 
a

\section{Bone marrow transplantation}

Monitoring
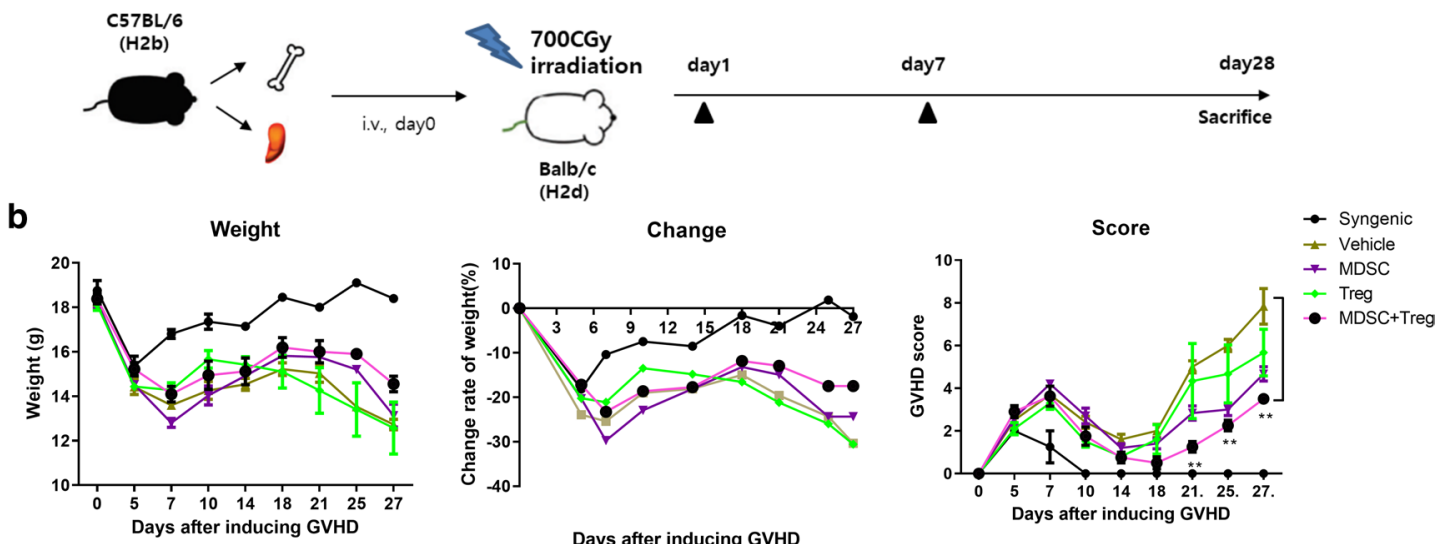

Days after inducing GVHD
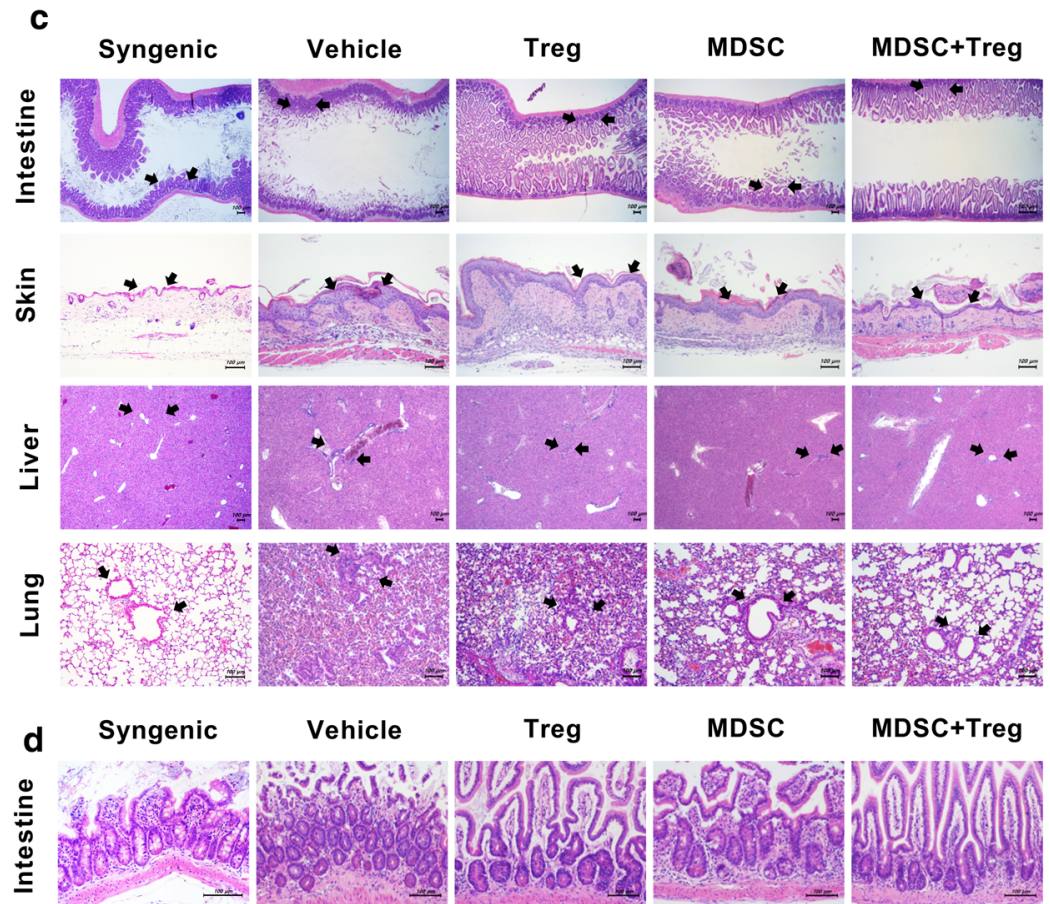

\section{Vehicle}

Treg

MDSC
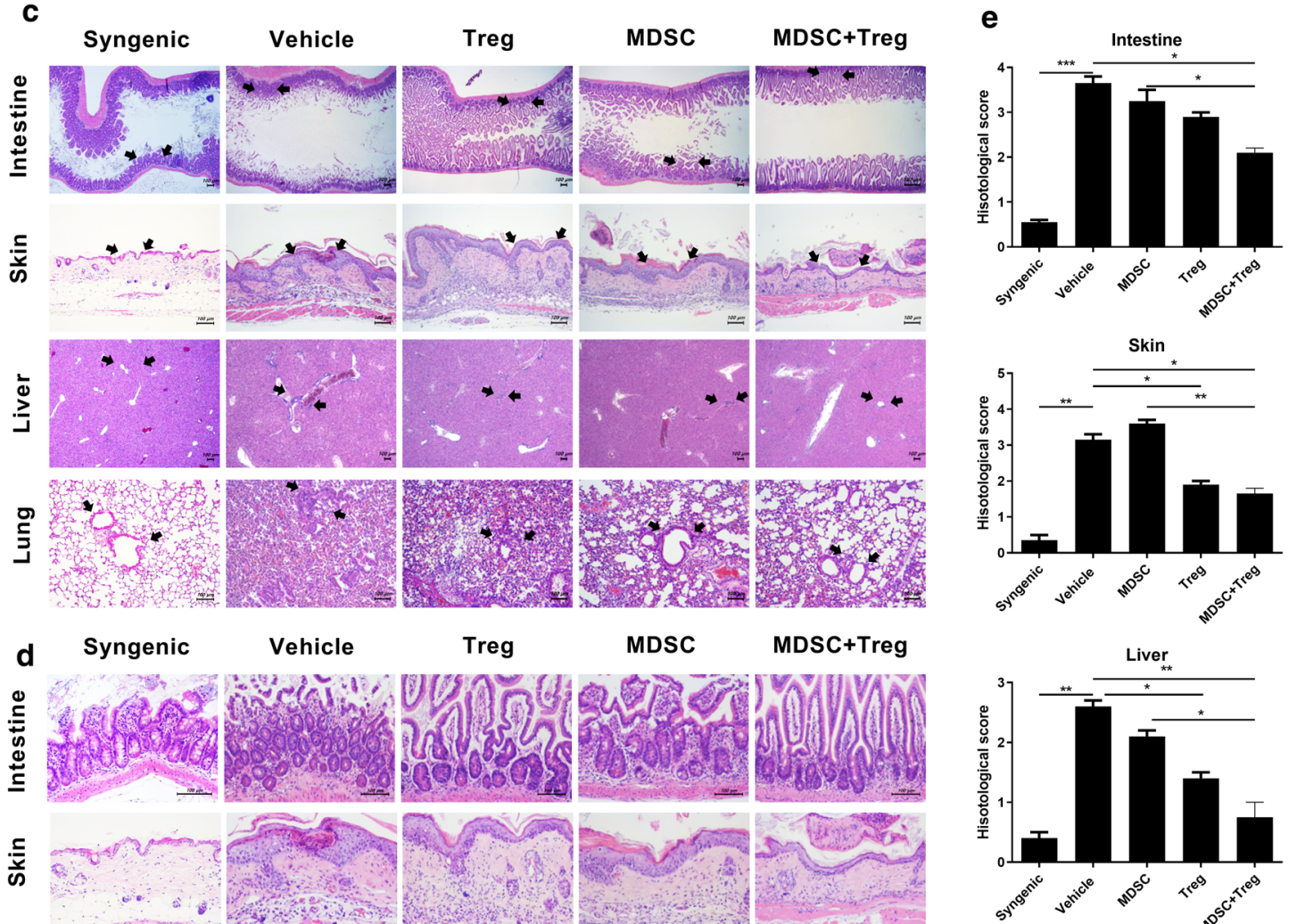

MDSC+Treg
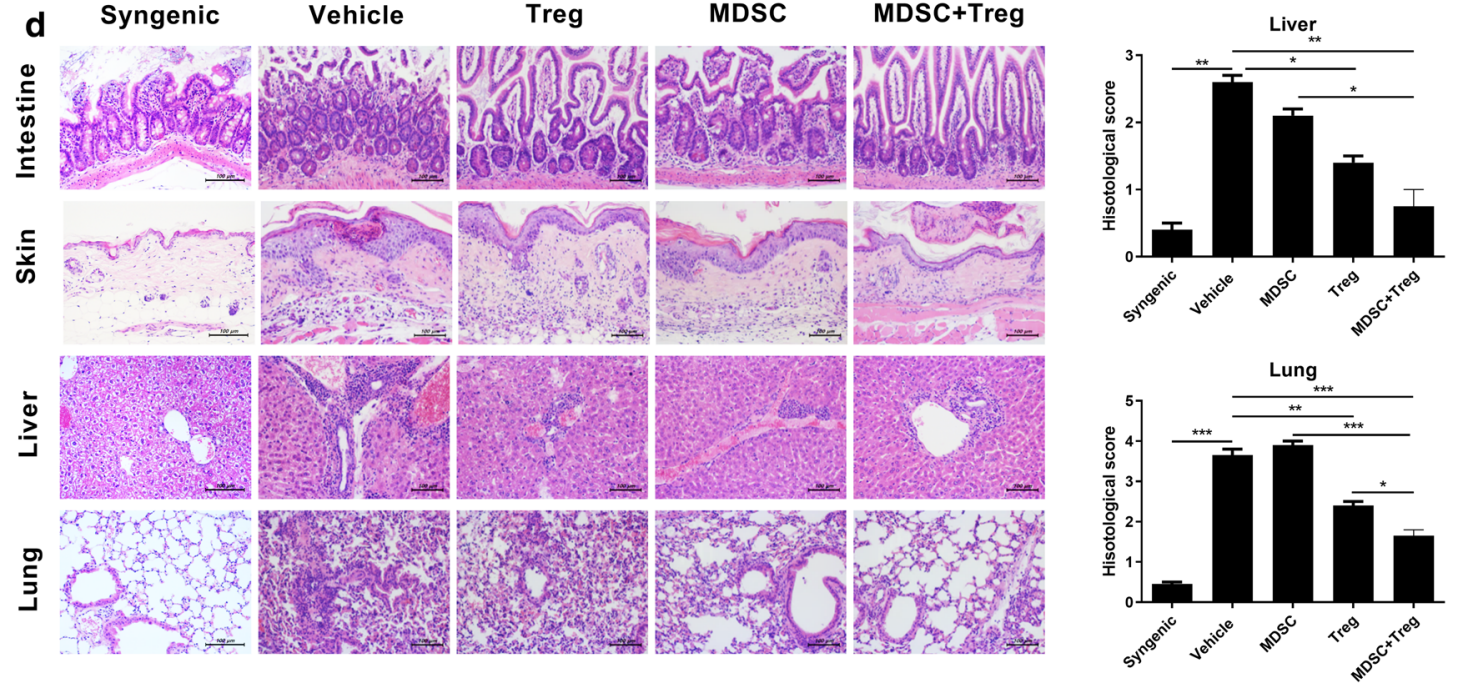


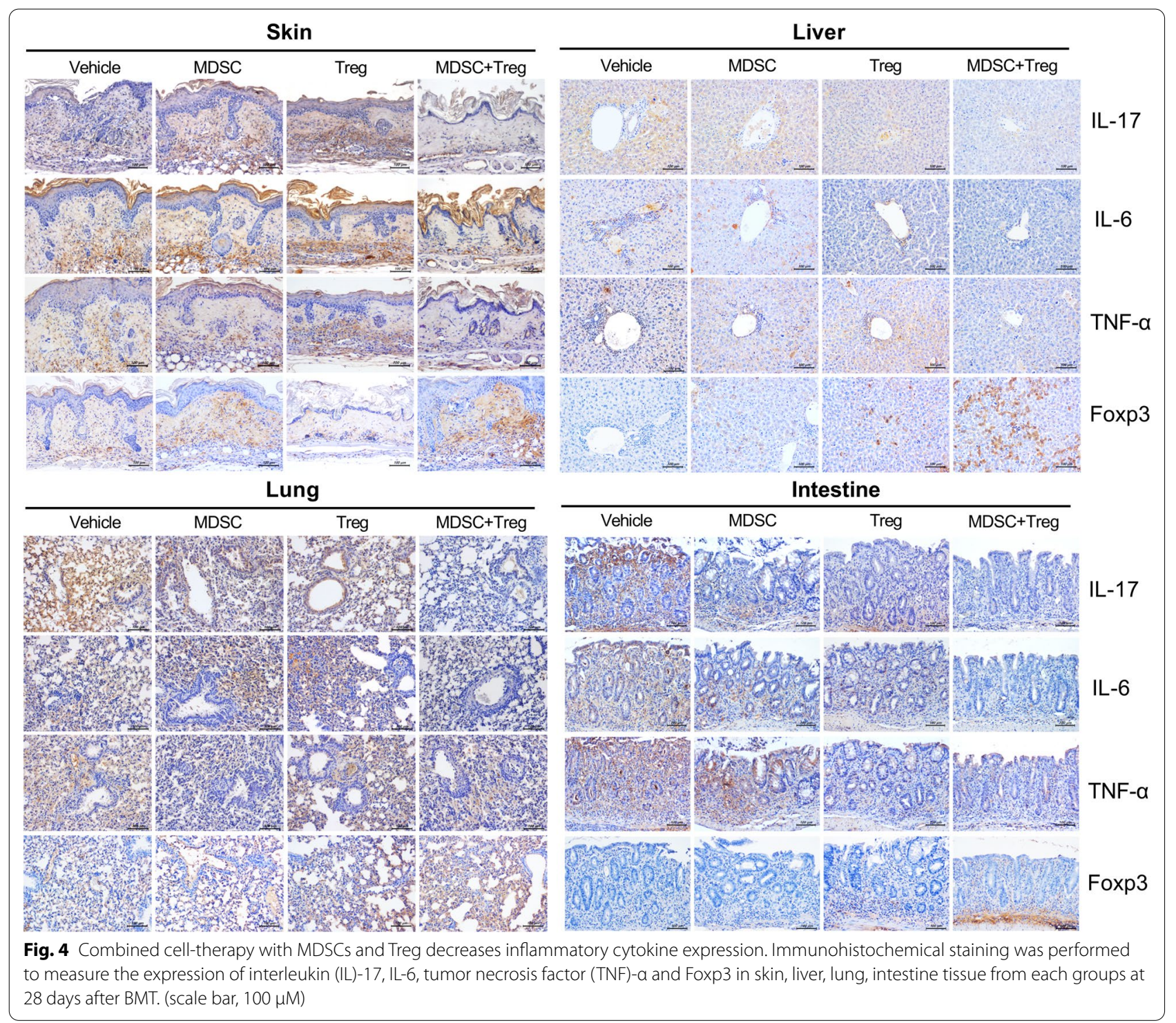

the results are still controversial [47, 48]. Furthermore the origin, delivery route, dose, and timing of infused MSCs influences therapeutic efficacy. MSC therapy is also insufficient to inhibit production of pro-inflammatory cytokines and reversed MSC-mediated therapetic efficacy under inflammatory condition $[49,50]$. It was reported that procoagulant tissue factor expression of MSCs by intravascular infusion trigger the instant bloodmediated inflammatory reaction (IBMIR), which in turn activate coagulation. These various problems in MSC therapy impede clinical applications [51]. We therefore suggest that MDSCs plus Treg combination therapy would be an alternative new treatment against GVHD that overcomes the limitations of MSC based therapy. Human MDSC therapy has been difficult to use clinically due to the limited number of MDSCs. However, recent studies have shown that the development of large-scale extended MDSCs offers the potential for use in clinical research. [17]

Our research has some limitations. First, only female recipient and donor mice were used. Minor histocompatibility associated with sex chromosomes affects the incidence and severity of the GHVD model. Gender-related factors have a significant impact on HSCT results [52, 53]. Our model requires further research to confirm the therapeutic effects of sex differentiation between recipients and donors. Second, the combination of MDSC and Treg did not demonstrate a GVL effect. To optimize the balance between GVHD and GVL in allogeneic stem cell transplantation, allogeneic HSCT must be successful. 


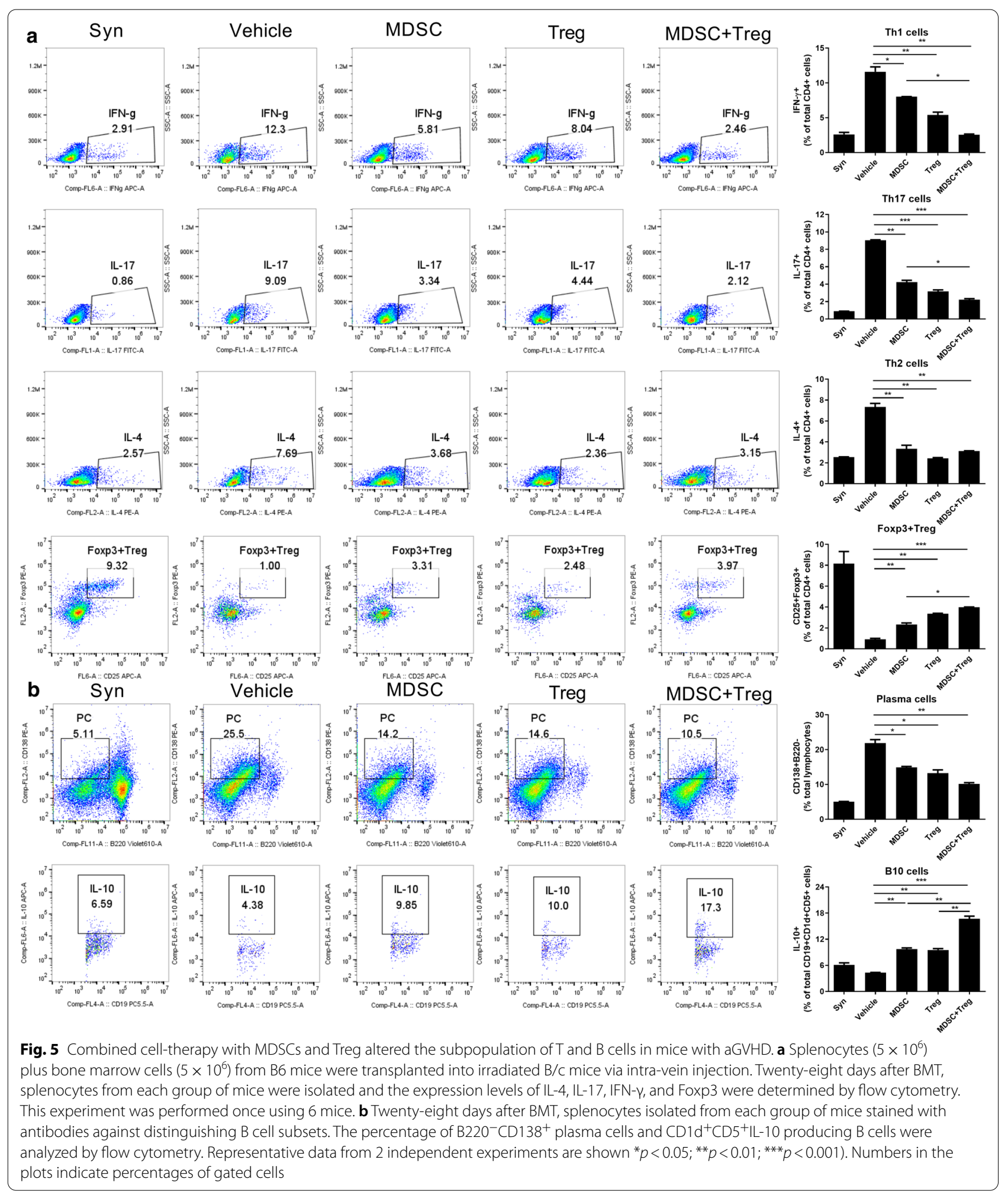




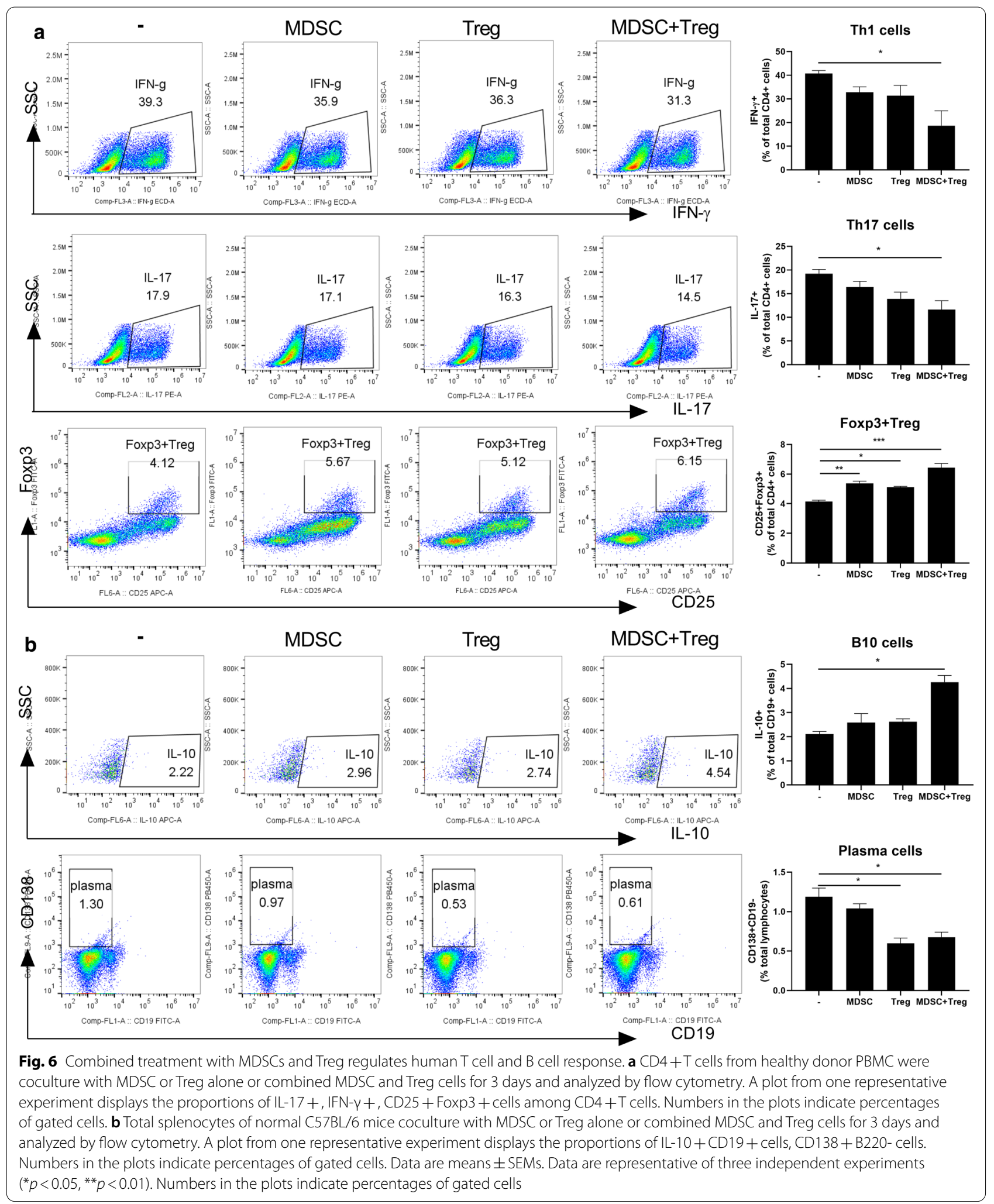


MDSC improved the severity and mortality of GVHD while maintaining GVL activity [54]. Allogeneic iTregs can weaken GVHD, but can significantly impair GVL function [55]. Further research is needed to confirm the GVL effect of the combination of MDSC and Treg. Despite these limitations, this was the first study to evaluate the effectiveness of MDSC and Treg combination therapy in a GVHD model. Previous studies reported an inhibitory effect on GVHD with a single treatment of each MDSC and Treg, but this study showed a synergistic effect of GVHD treatment with a combination of MDSC and Treg. Therefore, the results of this study provide a potential strategy for mitigating GVHD by overcoming the limitations of future single-cell therapies.

\section{Conclusion}

In conclusion, the combination of MDSCs and Tregs had a synergistic immunoregulatory effect by increasing the Treg/Breg populations and decreasing the populations of effector Th1 and Th17 cells, which ameliorated GVHD development. Taken together, this study demonstrates that combined therapy of MDSCs and Treg cells with fewer side effects than current immunosuppressant drugs has potential for treating aGVHD and should be evaluated in clinical trials.

\section{Supplementary Information}

The online version contains supplementary material available at https://doi. org/10.1186/s12967-020-02657-6.

Additional file 1: Table S1. Clinical GVHD scoring system.

Additional file 2: Figure S1. In vitro does test of combined cell-therapy with MDSC and Treg on Treg/Th17 regulation.

Additional file 3: Figure S2. Combined cell-therapy with MDSCs and Treg decreases inflammatory cytokine and Foxp3 expression.

Additional file 4: Figure S3. Combined cell-therapy with MDSCs and Treg altered the subpopulation of T cell in peripheral blood.

\section{Abbreviations}

MDSC: Myeloid-derived suppressor cells; Tregs: Regulatory T cells; GHVD: Graft-versus-host disease; HSCT: Hematopoietic stem cell transplantation; BMT: Bone marrow transplantation; BMC: Bone marrow-derived cells; APCs: Antigen-presenting cells; iNOS: Inducible nitric oxide synthetase; SLE: Systemic

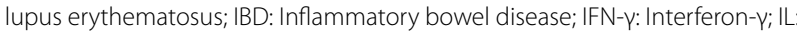
Interleukin; Th: Thelper.

\section{Acknowledgements}

None.

\section{Authors' contributions}

MJP (study concept and design, analysis and interpretation of data, statistical analysis, drafting and critical revision of the manuscript); JAB (acquisition of data, analysis and interpretation of data, statistical analysis, drafting of the manuscript); SYK (acquisition of data, analysis and interpretation of data, statistical analysis, drafting of the manuscript); KAJ (analysis and interpretation of data, drafting of the manuscript); JWC (analysis and interpretation of data, drafting of the manuscript), SHP (study concept and design, drafting of the manuscript); SKK (study concept and design, analysis and interpretation of data, drafting of the manuscript); MLC (study concept and design, acquisition of data, analysis and interpretation of data, drafting of the manuscript, critical revision of the manuscript for important intellectual content, study supervision). All authors read and approved the final manuscript.

\section{Funding}

This research was supported by a grant of the Korea Health Technology R\&D Project through the Korea Health Industry Development Institute (KHIDI), funded by the Ministry of Health \& Welfare, Republic of Korea (Grant Number:HI16C1888). This research was supported by Basic Science Research Program through the National Research Foundation of Korea (NRF) funded by the Ministry of Education (2020R1/1A1A01072525)

\section{Availability of data and materials}

All data are available in the manuscript or upon request to the authors.

\section{Ethics approval and consent to participate}

All animal experiments were performed in accordance with the animal care and use committee of The Catholic University of Korea approved the protocols (Approval numbers: CUMS-2017-0215-03). Peripheral blood mononuclear cells (PBMCs) obtained from normal healthy humans were separated from buffy coats using Ficoll-Hypaque (Pharmacia Biotech, Piscataway, NJ, USA). All human experimental procedures were approved by the Ethics Committee of Seoul St. Mary's Hospital (Seoul, Republic of Korea, KC17TNSI0570).

\section{Consent for publication}

Not applicable.

\section{Competing interests}

The authors declare that they have no competing interests.

\section{Author details}

${ }^{1}$ The Rheumatism Research Center, Catholic Research Institute of Medical Science, The Catholic University of Korea, 505 Banpo-dong, Seocho-gu, Seoul 137-040, South Korea. ${ }^{2}$ Divison of Rheumatology, Department of Internal Medicine, Seoul St. Mary's Hospital, College of Medicine, The Catholic University of Korea, Seoul, South Korea.

Received: 23 June 2020 Accepted: 2 December 2020

Published online: 14 December 2020

\section{References}

1. Shlomchik WD. Graft-versus-host disease. Nat Rev Immunol. 2007;7:340-52.

2. Zeiser R, Blazar BR. Preclinical models of acute and chronic graft-versushost disease: how predictive are they for a successful clinical translation? Blood. 2016;127:3117-26.

3. Toubai T, Tanaka J, Paczesny S, Shono Y, Reddy P, Imamura M. Role of cytokines in the pathophysiology of acute graft-versus-host disease (GVHD): are serum/plasma cytokines potential biomarkers for diagnosis of acute GVHD following allogeneic hematopoietic cell transplantation (Allo-HCT)? Curr Stem Cell Res Ther. 2012;7:229-39.

4. Blazar BR, Murphy WJ, Abedi M. Advances in graft-versus-host disease biology and therapy. Nat Rev Immunol. 2012;12:443-58.

5. Zeiser R, Blazar BR. Acute graft-versus-host disease-biologic process, prevention, and therapy. N Engl J Med. 2017;377:2167-79.

6. Gabrilovich DI, Nagaraj S. Myeloid-derived suppressor cells as regulators of the immune system. Nat Rev Immunol. 2009;9:162-74.

7. Gabrilovich DI. Myeloid-derived suppressor cells. Cancer Immunol Res. 2017;5:3-8

8. Kwak Y, Kim HE, Park SG. Insights into myeloid-derived suppressor cells in inflammatory diseases. Arch Immunol Ther Exp (Warsz). 2015;63:269-85.

9. Yang H, Bi Y, Han F, Lu Y, Wang J, Zhang Z, Liu G. Myeloid-derived suppressor cells in immunity and autoimmunity. Expert Rev Clin Immunol. 2015;11:911-9.

10. Ma H, Xia CQ. Phenotypic and functional diversities of myeloidderived suppressor cells in autoimmune diseases. Mediators Inflamm. 2018;2018:4316584. 
11. Zhang Q, Fujino M, Xu J, Li XK. The role and potential therapeutic application of myeloid-derived suppressor cells in allo- and autoimmunity. Mediators Inflamm. 2015;2015:421927.

12. Koehn BH, Blazar BR. Role of myeloid-derived suppressor cells in allogeneic hematopoietic cell transplantation. J Leukoc Biol. 2017;102:335-41.

13. Pyzer AR, Cole L, Rosenblatt J, Avigan DE. Myeloid-derived suppressor cells as effectors of immune suppression in cancer. Int J Cancer. 2016;139:1915-26.

14. Park MJ, Lee SH, Kim EK, Lee EJ, Park SH, Kwok SK, Cho ML. Myeloidderived suppressor cells induce the expansion of regulatory $b$ cells and ameliorate autoimmunity in the sanroque mouse model of systemic lupus erythematosus. Arthritis Rheumatol. 2016;68:2717-27.

15. Highfill SL, Rodriguez PC, Zhou Q, Goetz CA, Koehn BH, Veenstra R, Taylor PA, Panoskaltsis-Mortari A, Serody JS, Munn DH, et al. Bone marrow myeloid-derived suppressor cells (MDSCs) inhibit graft-versus-host disease (GVHD) via an arginase-1-dependent mechanism that is up-regulated by interleukin-13. Blood. 2010;116:5738-47.

16. Messmann JJ, Reisser T, Leithauser F, Lutz MB, Debatin KM, Strauss G. In vitro-generated MDSCs prevent murine GVHD by inducing type $2 \mathrm{~T}$ cells without disabling antitumor cytotoxicity. Blood. 2015;126:1138-48.

17. Park MY, Lim BG, Kim SY, Sohn HJ, Kim S, Kim TG. GM-CSF promotes the expansion and differentiation of cord blood myeloid-derived suppressor cells, which attenuate xenogeneic graft-vs-host disease. Front Immunol. 2019;10:183.

18. Bluestone JA, Tang Q. Treg cells-the next frontier of cell therapy. Science. 2018;362:154-5.

19. Chen Y, Colello J, Jarjour W, Zheng SG. Cellular metabolic regulation in the differentiation and function of regulatory T cells. Cells. 2019;8:188.

20. Golshayan D, Jiang S, Tsang J, Garin MI, Mottet C, Lechler RI. In vitroexpanded donor alloantigen-specific CD4+CD25+ regulatory T cells promote experimental transplantation tolerance. Blood. 2007:109:827-35.

21. Pilat N, Granofszky N, Wekerle T. Combining adoptive treg transfer with bone marrow transplantation for transplantation tolerance. Curr Transplant Rep. 2017:4:253-61.

22. Romano M, Tung SL, Smyth LA, Lombardi G. Treg therapy in transplantation: a general overview. Transpl Int. 2017;30:745-53.

23. Grant CR, Liberal R, Mieli-Vergani G, Vergani D, Longhi MS. Regulatory T-cells in autoimmune diseases: challenges, controversies and-yet-unanswered questions. Autoimmun Rev. 2015;14:105-16.

24. Hanash AM, Levy RB. Donor CD4+CD25+T cells promote engraftment and tolerance following MHC-mismatched hematopoietic cell transplantation. Blood. 2005;105:1828-36.

25. Brunstein CG, Miller JS, Cao Q, McKenna DH, Hippen KL, Curtsinger J, Defor T, Levine BL, June CH, Rubinstein P, et al. Infusion of ex vivo expanded T regulatory cells in adults transplanted with umbilical cord blood: safety profile and detection kinetics. Blood. 2011;117:1061-70.

26. Sakaguchi S, Vignali DA, Rudensky AY, Niec RE, Waldmann H. The plasticity and stability of regulatory T cells. Nat Rev Immunol. 2013;13:461-7.

27. Dijke IE, Hoeppli RE, Ellis T, Pearcey J, Huang Q, McMurchy AN, Boer K, Peeters AM, Aubert G, Larsen I, et al. Discarded human thymus is a novel source of stable and long-lived therapeutic regulatory T cells. Am J Transplant. 2016;16:58-71.

28. Lee CR, Kwak Y, Yang T, Han JH, Park SH, Ye MB, Lee W, Sim KY, Kang JA, Kim YC, et al. Myeloid-derived suppressor cells are controlled by regulatory T cells via TGF-beta during Murine Colitis. Cell Rep. 2016;17:3219-32.

29. Weber M, Stein P, Prufer S, Rudolph B, Kreft A, Schmitt E, Bopp T, Roers A, Schild H, Fillatreau S, Radsak MP. Donor and host B cell-derived IL-10 contributes to suppression of graft-versus-host disease. Eur J Immunol. 2014:44:1857-65.

30. van de Veen W, Stanic B, Wirz OF, Jansen K, Globinska A, Akdis M. Role of regulatory $B$ cells in immune tolerance to allergens and beyond. J Allergy Clin Immunol. 2016;138:654-65.

31. Fukui J, Inaba M, Ueda Y, Miyake T, Hosaka N, Kwon AH, Sakaguchi Y, Tsuda M, Omae M, Kamiyama Y, Ikehara S. Prevention of graft-versushost disease by intra-bone marrow injection of donor T cells. Stem Cells. 2007:25:1595-601.

32. Kim SY, Park MJ, Kwon JE, Jung KA, Jhun JY, Lee SY, Seo HB, Ryu JY, Beak JA, Choi JY, Cho ML. Cucurbitacin E ameliorates acute graft-versus-host disease by modulating Th17 cell subsets and inhibiting STAT3 activation. Immunol Lett. 2018;203:62-9.
33. Kang X, Zhang X, Liu Z, Xu H, Wang T, He L, Zhao A. Granulocytic myeloidderived suppressor cells maintain feto-maternal tolerance by inducing Foxp3 expression in CD4+CD25-T cells by activation of the TGF-beta/ beta-catenin pathway. Mol Hum Reprod. 2016;22:499-511.

34. Wang K, Lv M, Chang YJ, Zhao XY, Zhao XS, Zhang YY, Sun YQ, Wang ZD, Suo P, Zhou Y, et al. Early myeloid-derived suppressor cells (HLA-DR(-)/ (low)CD33(+)CD16(-)) expanded by granulocyte colony-stimulating factor prevent acute graft-versus-host disease (GVHD) in humanized mouse and might contribute to lower GVHD in patients post allo-HSCT. J Hematol Oncol. 2019;12:31.

35. Hoffmann P, Ermann J, Edinger M, Fathman CG, Strober S. Donor-type CD4(+)CD25(+) regulatory T cells suppress lethal acute graft-versushost disease after allogeneic bone marrow transplantation. J Exp Med. 2002;196:389-99.

36. Edinger M, Hoffmann P, Ermann J, Drago K, Fathman CG, Strober S, Negrin RS. CD4+CD25+ regulatory T cells preserve graft-versus-tumor activity while inhibiting graft-versus-host disease after bone marrow transplantation. Nat Med. 2003;9:1144-50.

37. Gaidot A, Landau DA, Martin GH, Bonduelle O, Grinberg-Bleyer Y, Matheoud D, Gregoire S, Baillou C, Combadiere B, Piaggio E, Cohen JL. Immune reconstitution is preserved in hematopoietic stem cell transplantation coadministered with regulatory T cells for GVHD prevention. Blood. 2011;117:2975-83.

38. Di lanni M, Falzetti F, Carotti A, Terenzi A, Castellino F, Bonifacio E, Del Papa B, Zei T, Ostini Rl, Cecchini D, et al. Tregs prevent GVHD and promote immune reconstitution in HLA-haploidentical transplantation. Blood. 2011;117:3921-8

39. Romano M, Fanelli G, Albany CJ, Giganti G, Lombardi G. Past, Present, and Future of Regulatory T Cell Therapy in Transplantation and Autoimmunity. Front Immunol. 2019;10:43.

40. Elias S, Rudensky AY. Therapeutic use of regulatory T cells for graft-versushost disease. Br J Haematol. 2019. https://doi.org/10.1111/bjh.16157.

41. Hu Y, He GL, Zhao XY, Zhao XS, Wang Y, Xu LP, Zhang XH, Yu XZ, Liu KY, Chang $Y J$, Huang XJ. Regulatory B cells promote graft-versus-host disease prevention and maintain graft-versus-leukemia activity following allogeneic bone marrow transplantation. Oncoimmunology. 2017;6:e1284721.

42. Chakupurakal G, Garcia-Marquez MA, Shimabukuro-Vornhagen A, Kluth S, Schlosser H, Theurich S, Scheid C, Hallek M, Holtick U, von BergweltBaildon M. Regulatory B10 cells display an altered homoeostasis in acute graft-versus-host disease. Eur J Haematol. 2017;98:128-33.

43. Lee JH, Jeon EJ, Kim N, Nam YS, Im KI, Lim JY, Kim EJ, Cho ML, Han KT, Cho SG. The synergistic immunoregulatory effects of culture-expanded mesenchymal stromal cells and CD4(+)25(+)Foxp3+ regulatory T cells on skin allograft rejection. PLOS ONE. 2013;8:e70968.

44. Im KI, Park MJ, Kim N, Lim JY, Park HS, Lee SH, Nam YS, Lee ES, Lee JH, Cho $\mathrm{ML}$, Cho SG. Induction of mixed chimerism using combinatory cell-based immune modulation with mesenchymal stem cells and regulatory $T$ cells for solid-organ transplant tolerance. Stem Cells Dev. 2014;23:2364-76.

45. Lim JY, Park MJ, Im KI, Kim N, Jeon EJ, Kim EJ, Cho ML, Cho SG. Combination cell therapy using mesenchymal stem cells and regulatory T-cells provides a synergistic immunomodulatory effect associated with reciprocal regulation of $\mathrm{TH} 1 / \mathrm{TH} 2$ and th17/treg cells in a murine acute graft-versus-host disease model. Cell Transplant. 2014;23:703-14.

46. Negi N, Griffin MD. Effects of mesenchymal stromal cells on regulatory T cells: Current understanding and clinical relevance. Stem Cells. 2020;38(5):596-605.

47. Godoy JAP, Paiva RMA, Souza AM, Kondo AT, Kutner JM, Okamoto OK. Clinical translation of mesenchymal stromal cell therapy for graft versus host disease. Front Cell Dev Biol. 2019;7:255.

48. Gregoire C, Ritacco C, Hannon M, Seidel L, Delens L, Belle L, Dubois S, Veriter S, Lechanteur C, Briquet A, et al. Comparison of mesenchymal stromal cells from different origins for the treatment of graft-vs-host-disease in a humanized mouse model. Front Immunol. 2019;10:619.

49. Lee SH. The advantages and limitations of mesenchymal stem cells in clinical application for treating human diseases. Osteoporos Sarcopenia. 2018:4:150

50. Lukomska B, Stanaszek L, Zuba-Surma E, Legosz P, Sarzynska S, Drela K. Challenges and controversies in human mesenchymal stem cell therapy. Stem Cells Int. 2019;2019:9628536.

51. Moll G, Ankrum JA, Kamhieh-Milz J, Bieback K, Ringden O, Volk HD, Geissler S, Reinke P. Intravascular mesenchymal stromal/stem cell therapy 
product diversification: time for new clinical guidelines. Trends Mol Med. 2019;25:149-63.

52. Kim HT, Zhang MJ, Woolfrey AE, St Martin A, Chen J, Saber W, Perales MA, Armand P, Eapen M. Donor and recipient sex in allogeneic stem cell transplantation: what really matters. Haematologica. 2016;101:1260-6.

53. Ok JP, Kociban DL, Machen LL, Buffo MJ. Effect of donor and recipient gender disparities on fatal graft-vs-host disease in a mouse model for major histocompatibility complex-matched unrelated-donor bone marrow transplantation. Exp Hematol. 1993;21:1570-6.

54. Zhang J, Chen HM, Ma G, Zhou Z, Raulet D, Rivera AL, Chen SH, Pan PY. The mechanistic study behind suppression of GVHD while retaining GVL activities by myeloid-derived suppressor cells. Leukemia. 2019;33:2078-89.

55. Heinrichs J, Bastian D, Veerapathran A, Anasetti C, Betts B, Yu XZ. Regulatory T-cell therapy for graft-versus-host disease. J Immunol Res Ther. 2016;1:1-14.

\section{Publisher's Note}

Springer Nature remains neutral with regard to jurisdictional claims in published maps and institutional affiliations.
Ready to submit your research? Choose BMC and benefit from:

- fast, convenient online submission

- thorough peer review by experienced researchers in your field

- rapid publication on acceptance

- support for research data, including large and complex data types

- gold Open Access which fosters wider collaboration and increased citations

- maximum visibility for your research: over 100M website views per year

At BMC, research is always in progress.

Learn more biomedcentral.com/submissions 